\title{
PENINGKATAN BAHASA ANAK USIA 5-6 TAHUN MELALUI MODEL PEMBELAJARAN STUDENT TEAMS ACHIEVEMENT DIVISION (STAD) DI TK ABA 30 MEDAN
}

\author{
Rismauli Syarifah Saragih \\ Guru TK ABA 30 Medan \\ Surel : rismaulisyarifah@gmail.com
}

\begin{abstract}
ABSTRAK
Tujuan penelitian ini adalah untuk meningkatkan kemampuan bahasa dengan menggunakan Model pembelajaran Student Teams Achievement Division (STAD). Proses penelitian dilakukan melalui 2 siklus. Pengumpulan data menggunakan lembar observasi. Hasil observasi dan refleksi pada siklus I setelah melaksanakan model pembelajaran Student Teams Achievement Division (STAD) diketahui bahwa peningkatan bahasa anak yaitu: 8 orang anak $(50 \%)$ pada kriteria baik, 6 orang anak (38\%) pada kriteria cukup dan 2 orang anak (12\%) pada kriteria kurang. Nilai rata-rata siklus I yaitu 61,11 (cukup). Pada siklus ini kemampuan klasikal belum tercapai karena kemampuan klasikal anak pada kriteria baik $(65-84)$ lebih rendah dari $75 \%$ yaitu $50 \%$. Dari hasil observasi tersebut dapat diketahui bahwa perlu dilakukan pembelajaran melalui model pembelajaran Student Teams Achievement Division (STAD) yang lebih baik pada siklus II. Pada siklus II setelah dilakukan perbaikan maka diketahui bahwa peningkatan bahasa anak meningkat yaitu 7 orang anak (44\%) tergolong sangat baik, dan 9 orang anak (56\%) tergolong baik.
\end{abstract}

Kata Kunci : Student Teams Achievement Division (STAD), Bahasa

\section{PENDAHULUAN}

Pengembangan kemampuan berbahasa pada anak usia dini adalah hal yang penting dilakukan, karena anak usia dini yaitu anak yang berumur 0-6 tahun dan usia tersebut merupakan usia keemasan (Golden Age) dimana dalam masa tersebut proses anak akan mengalami perkembangan pada dirinya baik itu fisik, moral, intelektual, sosial emosional maupun bahasa.

Pada hakekatnya, belajar bahasa adalah belajar berkomunikasi. Untuk itulah pengajaran bahasa bertujuan agar anak dapat menggunakan bahasa dengan baik dan benar terutama dalam kegiatan proses pembelajaran dan meningkatkan kemampuan penalaran serta kematangan emosional dan sosial.

Pengajaran bahasa lebih menekankan pada keterampilan menggunakan (psikomotor) bahasa tersebut. Perkembangan bahasa pada anak usia dini sangat penting karena dengan bahasa anak dapat memperoleh pengembangan kemampuan yang berlangsung secara terus menerus, untuk itu pendidik perlu merancang pembelajaran yang akan menumbuhkan ide-ide yang dimilikinya untuk mengembangkan kemampuan berbahasa anak, memberikan contoh penggunaan bahasa yang baik dan benar, menstimulasi perkembangan bahasa anak dengan berkomunikasi secara aktif. 
Menurut Miller (Agustin, 2010:15) bahasa adalah suatu urutan kata-kata, bahasa juga dapat digunakan untuk menyampaikan informasi mengenai tempat yang berbeda atau waktu yang berbeda. Pada usia 3-6 tahun kemampuan berbahasa anak akan berkembang sejalan dengan rasa ingin tahu serta sikap antusias yang tinggi, sehingga timbul pertanyaan-pertanyaan dari anak dengan kemampuan bahasanya.

Antara usia 4 dan 5 tahun, kalimat anak sudah terdiri dari empat sampai lima kata. Antara 5 dan 6 tahun, kalimat anak sudah terdiri dari enam sampai delapan kata. Mereka juga sudah dapat menjelaskan arti kata-kata sederhana, mengetahui lawan kata. Mereka dapat menggunakan kata penghubung, kata depan dan kata sandang.

Pada masa akhir usia prasekolah anak umumnya sudah mampu berkata-kata sederhana, cara bicara mereka telah lancar, dapat dimengerti dan cukup mengikuti tata bahasa walaupun masih melakukan kesalahan berbahasa.

yang dilakukan peneliti pada Kelompok B di TK ABA 30 Jl. Karya Gang. Madrasah No. 24 Medan diperoleh bahwa kemampuan berbahasa anak masih rendah, hal itu dapat dilihat masih ditemukan ada siswa kurang lancar berbahasa, menggunakan kata tertentu masih celat, dan masih ada anak yang sulit memahami bahasa sehingga sering tidak mengerti apa yang kita tanya. Ini juga diakibatkan karena sebagian orangtua anak didik di lingkungan keluarga kurang kreatif dalam mengajak anak untuk bercakap-cakap, kurangnya perhatian orangtua, sebagian anak diasuh pembantu dalam melaksanakan tugasnya kurang mengajak anak untuk bercakap-cakap, kurangnya kemampuan guru dalam mengembangkan perbendaharaan kata anak.

Dalam pelaksanaan proses pembelajaran di dalam kelas, guru kurang mengajak anak berinteraksi dengan anak sesuai dengan perkembangan bahasa anak (dominan guru/metode).

Salah satu cara yang tepat digunakan dalam meningkatkan bahasa anak usia dini adalah dengan menerapkan model pembelajaran Student Teams Achievement Division (STAD). Model pembelajaran STAD merupakan salah satu dari sekian banyak model pembelajaran kooperatif.

Pada dasarnya pembelajaran kooperatif mengandung pengertian sebagai suatu sikap atau perilaku bersama dalam bekerja atau membantu di antara sesama dalam struktur kerja sama yang teratur dalam kelompok, yang terdiri dari dua orang atau lebih di mana keberhasilan kerja sangat dipengaruhi oleh keterlibatan dari setiap anggota kelompok itu sendiri.

Pembelajaran kooperatif juga dapat diartikan sebagai suatu struktur tugas bersama dalam suasana kebersamaan di antara sesama anggota kelompok. 
Menurut Slavin (Istarani, 2012:19) menyatakan bahwa pada model pembelajaran ini siswa ditempatkan dalam tim belajar beranggotakan 4-5 orang yang merupakan campuran menurut tingkat prestasi, jenis kelamin, dan suku.

Guru menyajikan pelajaran, dan kemudian siswa bekerja dalam tim mereka memastikan bahwa seluruh anggota tim telah menguasai pelajaran tersebut. Kemudian, seluruh siswa diberikan tes tentang materi tersebut, pada saat tes ini mereka tidak diperbolehkan saling membantu. Adapun langkah-langkah terukur dan sistematis dari model pembelajaran ini sebagai berikut:

a. Membentuk kelompok yang anggotanya \pm 4 orang secara heterogen (prestasi, jenis kelamin, suku dan lain-lain.

b. Guru menyajikan pelajaran

c. Guru memberikan tugas kepada kelompok untuk dikerjakan oleh anggotan-anggota kelompok.

d. Guru memberi kuis / pertanyaan kepada seluruh peserta didik. Pada saat menjawab kuis tidak boleh saling membantu.

e. Memberi evaluasi

f. Kesimpulan.

Berdasarkan latar belakang
masalah, dapat dikaji adapun
permasalahan yang dirumuskan
sebagai berikut:Apakah dengan
penerapan model pembelajaran
Student Teams Achievement Division
(STAD) dapat meningkatkan bahasa anak usia 5-6 tahun di TK ABA 30 Tahun ajaran 2014/2015?

Merujuk pada rumusan masalah di atas, maka tujuan dilaksanakan penelitian ini adalahuntuk meningkatkan bahasa anak usia 5-6 tahun melalui penerapan model pembelajaran Student Teams Achievement Division (STAD) di TK ABA 30 Tahun ajaran 2014/2015.

\section{METODE PENELITIAN}

Penelitian ini dilakukan di TK ABA 30 J1. Karya Gang. Madrasah No. 24 Medan Tahun Ajaran 20142015 dan waktu penelitian direncanakan selama 5 Bulan (Maret 2015 s/d Juli 2015).

Subjek dalam penelitian ini adalah anak usia 5-6 tahun kelompok $B$ di TK ABA 30 Medan TA 2014/2015 yang berjumlah 16 orang.

Pengumpulan data dilakukan dengan mengggunakan Observasi, yaitu teknik yang dilakukan dengan cara pengamatan secara teliti dan sistematis. Observasi dilakukan untuk mendapatkan gambaran secara langsung peningkatan bahasa anak.

Adapun indikator bahasa anak yang diamati dan ditingkatkan dapat dilihat pada tabel berikut : 
Tabel 1 : Kisi-kisi Lembar

Observasi Bahasa Anak Usia 5-6

Tahun

\begin{tabular}{|c|c|c|}
\hline No & Indikator & Deskriptor \\
\hline 1. & $\begin{array}{l}\text { Menerima } \\
\text { bahasa }\end{array}$ & $\begin{array}{l}\text { 1.Mengerti beberapa } \\
\text { perintah secara } \\
\text { bersamaan. } \\
\text { 2.Mengulang kalimat yang } \\
\text { lebih kompleks } \\
\text { 3. Memahami aturan dalam } \\
\text { suatu permainan }\end{array}$ \\
\hline 2. & $\begin{array}{l}\text { Mengung- } \\
\text { kapkan } \\
\text { bahasa }\end{array}$ & $\begin{array}{l}\text { 1.Menjawab pertanyaan } \\
\text { yang lebih kompleks. } \\
\text { 2.Berkomunikasi secara } \\
\text { lisan, memiliki } \\
\text { perbendaharaan kata, } \\
\text { serta mengenal simbol- } \\
\text { simbol untuk persiapan } \\
\text { membaca, menulis dan } \\
\text { berhitung. } \\
\text { 3.Memiliki lebih banyak } \\
\text { kata-kata untuk } \\
\text { mengekpresikan ide pada } \\
\text { orang lain }\end{array}$ \\
\hline 3. & Keaksaraan & $\begin{array}{l}\text { 1.Menyebutkan simbol- } \\
\text { simbol huruf yang } \\
\text { dikenal. } \\
\text { 2. Mengenal suara } \\
\text { huruf awal dari nama } \\
\text { benda-benda yang ada di } \\
\text { sekitarnya } \\
\text { 3.Membaca nama sendiri }\end{array}$ \\
\hline
\end{tabular}

\section{Desain Penelitian}

Penelitian ini menggunakan desain model Arikunto (2012:16). Rancangan masing-masing siklus terdiri dari empat tahap yaitu perencanaan, pelaksanaan, pengamatan dan refleksi.

\section{Teknik Analisis Data}

Analisa ini dilakukan untuk mengetahui berhasil atau tidaknya tindakan yang dilakukan dalam penelitian ini. Analisis lembar observasi untuk mengetahui peningkatan bahasa anak. Pemaparan data dilakukan dengan mencari persentase peningkatan bahasa pada anak secara individu atau perorangan dengan rumus Sujino (dalam Tarigan, 2011) yaitu :

$$
\mathrm{Pi}=\frac{f}{n} \times 100 \%
$$

Dimana :

$\mathrm{Pi}=$ Persentase peningkatan bahasa pada anak.

$\mathrm{f}=$ jumlah skor yang diperoleh

$\mathrm{n}=$ jumlah skor keseluruhan

Setelah rumus untuk mencari perkembangan individu dilakukan, maka selanjutnya adalah mencari perkembangan rata-rata anak dengan menggunakan rumus :

$$
x=\frac{\sum x}{\sum n} \text { (Aqib, 2010:16) }
$$

Keterangan :

$\mathrm{x}=$ Nilai rata-rata

$\sum \mathrm{x}=$ Jumlah semua nilai anak

$\sum \mathrm{n}=$ Jumlah anak

Selanjutnya untuk mengetahui persentase peningkatan bahasa pada anak secara keseluruhan atau klasikal, maka digunakan rumus:

$$
P=\frac{f}{n} \mathrm{x} 100 \%
$$

(Dewi, 2010:188)

Keterangan :

$\mathrm{P}=$ persentase peningkatan bahasa pada anak.

$\mathrm{f}=$ jumlah subjek yang mengalami perubahan.

$\mathrm{n}=$ jumlah subjek keseluruhan

Dikatakan mengalami peningkatan bahasa anak apabila terdapat $75 \%$ telah mencapai keberhasilan minimum nilai 65 (Baik). 
HASIL PENELITIAN DAN

PEMBAHASAN

\section{Perencanaan Siklus I}

Sebelum melakukan tindakan siklus I, peneliti telah menyusun perencanaan pembelajaran yang akan dilaksanakan di dalam kelas, antara lain:
a. Peneliti merencanakan pembelajaran.
b. Peneliti membuat rencana pelaksanaan kegiatan.
c. Menyusun Rencana Kegiatan Harian (RKH).
d. Mempersiapkan bahan/media yang akan digunakan pada kegiatan pembelajaran.
e. Membuat lembar observasi.

\section{Tahap Pelaksanaan Siklus I}

Pada tahap ini kegiatan yang akan dilakukan adalah melaksanakan penelitian sesuai dengan rencana penelitian dengan mengutamakan tindakan yang akan dilaksanakan yaitu meningkatkan bahasa anak usia 5-6 tahun melalui model pembelajaran Student Teams Achievement Division (STAD).

I. Kegiatan awal
a) Berbaris
b) Mengucap salam
c) Berdoa sebelum belajar
d) Bernyanyi
e) Guru menyuruh anak untuk duduk dikelompoknya masing-masing.
f) Guru menjelaskan tentang materi pembelajaran.

II. Kegiatan Inti
a) Mengerjakan tugas yang diberikan guru secara berkelompok.

b) Melaksanakan kegiatan kuis.

c) Menjawab pertanyaan dari kuis yang diberikan secara mandiri (sendiri).

III. Istirahat/ Makan

IV. Kegiatan akhir
a) Evaluasi jawaban anak pada saat kuis.
b) Memberi kesimpulan dari kuis yang dilakukan.
c) Berdiskusi tentang kegiatan hari ini.
d) Doa, salam dan pulang.

\section{Hasil Pengamatan Siklus I}

Selama proses pembelajaran dengan model pembelajaran Student Teams Achievement Division (STAD), peneliti di bantu oleh guru pendamping sebagai mitra kolaborasi untuk mengamati seluruh aktivitas atau kegiatan pembelajaran dengan menggunakan lembar observasi yang telah disiapkan oleh peneliti.

Dalam pelaksanaan proses pembelajaran khususnya meningkatkan bahasa anak dengan model pembelajaran Student Teams Achievement Division (STAD), peneliti mengamati aktivitas anak dengan menggunakan lembar observasi yang telah dipersiapkan. Pelaksanaan penelitian dilakukan oleh peneliti dan dibantu oleh guru. Dari hasil pengamatan yang dilakukan pada siklus I dengan dua kali pertemuan, diketahui bahwa tindakan yang dilakukan peneliti belum 
optimal dalam meningkatkan bahasa. Hal ini terlihat pada tabel berikut:

Table 2: Hasil Pengamatan Peningkatan Bahasa Anak Selama Siklus I

\begin{tabular}{|c|c|c|c|c|}
\hline No. & Nilai & $\mathrm{N}$ & $\%$ & Ket \\
\hline 1. & $85-100$ & 0 & 0 & $\begin{array}{c}\text { Sangat } \\
\text { Baik }\end{array}$ \\
\hline 2. & $65-84$ & 8 & 50 & Baik \\
\hline 3. & $55-64$ & 6 & 38 & Cukup \\
\hline 4. & $0-54$ & 2 & 12 & Kurang \\
\hline \multicolumn{2}{|c|}{ Jumlah } & 16 & 100 & \\
\hline
\end{tabular}

Berdasarkan hasil pengamatan pada Siklus I Pertemuan kedua, peneliti melihat bahwa peningkatan bahasa anak belum meningkat dan masih cenderung rendah. Tabel $4.2 \mathrm{di}$ atas menunjukkan bahwa pada siklus I, peningkatan bahasa anak sebagai berikut: 8 orang anak (50\%) pada kriteria baik, 6 orang anak (38\%) pada kriteria cukup dan 2 orang anak (12\%) pada kriteria kurang. Nilai rata-rata siklus I yaitu 61,11 (cukup).

\section{Refleksi Siklus I}

Berdasarkan hasil observasi dan hasil belajar anak pada siklus 1, ditemukan sejumlah permasalahan anak, yaitu pada proses dan hasil belajar anak. Pada proses kegiatan pembelajaran, yaitu model pembelajaran Student Teams Achievement Division (STAD) masih banyak anak masih takut mengungkapkan jawaban dari kuis yang diberikan dan masih kurang aktif dalam melaksanakan kegiatan kuis. Untuk meningkatkan aspek yang masih kurang pada siklus 1, maka perlu adanya perbaikan untuk tindakan selanjutnya dengan cara sebagai berikut:

a. Mengoptimalkan penggunaan model pembelajaran yang dipakai guru.

b. Penggelolaan interaksi kelas harus tepat sehingga anak dapat belajar dengan baik dan menyenangkan.

Penggunaan alokasi waktu harus sesuai dengan alokasi waktu yang ditentukan sehingga ada waktu untuk diskusi dan tanya jawab.

\section{Hasil dan Pembahasan Siklus II Perencanaan Siklus II}

Berdasarkan hasil refleksi Siklus I yang telah dilaksanakan selama dua kali pertemuan, maka di peroleh hasil bahwa peningkatan bahasa anak masih tergolong rendah, untuk itu penelitian ini dilanjutkan ke siklus II.

Tahap perencanaan siklus II meliputi kegiatan:

1. Peneliti dan observer secara kolaboratif merencanakan pembelajaran.

2. Peneliti membuat rencana pelaksanaan kegiatan.

3. Menyusun Rencana Kegiatan Harian (RKH).

4. Guru lebih memotivasi anak, seperti memberikan kata-kata pujian agar anak lebih bersemangat dalam melakukan kegiatan pembelajaran.

5. Guru lebih memperhatikan waktu yang telah ditentukan agar semua 
kegiatan dapat berjalan dengan baik.

6. Membuat lembar observasi.

\section{Pelaksanaan Siklus II}

Pelaksanaan tindakan siklus II dilaksanakan selama dua kali pertemuan.Pada kegiatan ini, yang dilaksanakan adalah berupa perbaikan dari siklus I.

I. Kegiatan Awal

a) Berbaris.

b) Mengucap salam.

c) Berdoa sebelum belajar

d) Bernyanyi.

e) Guru menyuruh anak untuk duduk dikelompoknya masing-masing.

f) Guru menjelaskan tentang materi pembelajaran.

II. Kegiatan Inti

a) Mengerjakan tugas yang diberikan guru secara berkelompok.

b) Melaksanakan kegiatan kuis.

c) Menjawab pertanyaan dari kuis yang diberikan secara mandiri (sendiri).

III. Istirahat/ Makan

IV. Kegiatan akhir

a) Evaluasi jawaban anak pada saat kuis.

b) Memberi kesimpulan dari kuis yang dilakukan.

c) Berdiskusi tentang kegiatan hari ini.

d) Doa, salam dan pulang.

\section{Hasil Pengamatan Siklus II}

Hasil observasi yang dilakukan oleh peneliti di TK ABA 30 Medan, menunjukkan bahwa aktivitas peneliti selaku guru selama tindakan siklus II pada aspek penyediaan peralatan, menjelaskan tujuan kegiatan dengan baik, membimbing dan mengarahkan anak dalam melaksanakan kegiatannya, memotivasi, serta memberikan respon yang baik kepada hasil kerja anak dapat dilihat pada tabel berikut ini:

Table 3: Hasil Pengamatan

Peningkatan Bahasa Anak Pada Siklus II

\begin{tabular}{|c|c|c|c|c|}
\hline No. & Nilai & $\mathrm{N}$ & $\%$ & Ket \\
\hline 1. & $85-100$ & 7 & 44 & $\begin{array}{c}\text { Sangat } \\
\text { Baik }\end{array}$ \\
\hline 2. & $65-84$ & 9 & 56 & Baik \\
\hline 3. & $55-64$ & 0 & 0 & Cukup \\
\hline 4. & $0-54$ & 0 & 0 & Kurang \\
\hline \multicolumn{2}{|c|}{ Jumlah } & 16 & 100 & \\
\hline
\end{tabular}

Tabel 4.4 di atas, menunjukkan bahwa hingga pertemuan kedua pada siklus II, peningkatan bahasa anak berada pada: 7 orang anak (44\%) tergolong sangat baik, dan 9 orang anak (56\%) tergolong baik.

\section{Refleksi Siklus II}

Berdasarkan hasil observasi yang dilakukan guru selaku mitra kolaborasi, diperoleh bahwa aktivitas yang dilakukan peneliti selama melaksanakan tindakan siklus II pada pertemuan 1 dan 2 sudah tergolong baik .

Selanjutnya hasil observasi yang telah dilakukan selama siklus II dapat dilihat bahwa melalui model pembelajaran Student Teams Achievement Division (STAD) dapat 
meningkatkan bahasa anak, dimana pada pertemuan kedua siklus II, peningkatan bahasa anak sudah tergolong dalam kategori baik. Hal ini tampak dari hasil observasi yang dilakukan, yaitu 7 orang anak (44\%) dikategorikan sangat baik, dan 9 orang anak (56\%) dikategorikan baik.

Setelah dilakukan analisis dan refleksi siklus II, diperoleh kesimpulan bahwa model pembelajaran Student Teams Achievement Division (STAD) dapat meningkatkan bahasa anak 5-6 Tahun di TK ABA 30 Medan.

\section{Pembahasan Penelitian}

Model pembelajaran Student Teams Achievement Division (STAD) yang dilaksanakan di kelompok B pada anak usia 5-6 tahun di TK ABA 30 Medan merupakan penelitian tindakan yang bertujuan untuk meningkatkan bahasa anak. Penelitian ini dilaksanakan selama dua siklus, masing-masing siklus dilaksanakan dua kali pertemuan.

Model pembelajaran Student Teams Achievement Division (STAD) terbukti dapat meningkatkan bahasa anak. Anak dapat menjawab kuis yang diberikan dengan baik sesuai dengan tahapan-tahapannya serta anak terlihat ceria dan bersemangat ketika kegiatan berlangsung. Peningkatan bahasa anak pada model pembelajaran Student Teams Achievement Division (STAD) hingga akhir pertemuan setiap siklus secara ringkas dirangkum pada tabel 4.5 berikut ini :
Table 4: Rangkuman Peningkatan Kecerdasan Kinestetik Anak Pada Siklus I dan II

\begin{tabular}{|l|c|c|c|c|c|c|}
\hline \multirow{2}{*}{ No } & \multirow{2}{*}{ Nilai } & \multirow{2}{*}{ Ket } & \multicolumn{2}{|c|}{ Siklus I } & \multicolumn{2}{c|}{ Siklus II } \\
\cline { 4 - 7 } & & & $\mathrm{N}$ & $\%$ & $\mathrm{~N}$ & $\%$ \\
\hline 1 & $85-100$ & $\begin{array}{c}\text { Sangat } \\
\text { Baik }\end{array}$ & 0 & 0 & 7 & 44 \\
\hline 2 & $65-84$ & Baik & 8 & 50 & 9 & 56 \\
\hline 3 & $55-64$ & Cukup & 6 & 38 & 0 & 0 \\
\hline 4 & $0-54$ & $\begin{array}{c}\text { Kuran } \\
\mathrm{g}\end{array}$ & 2 & 12 & 0 & 0 \\
\hline \multicolumn{3}{|c|}{ Jumlah } & 16 & 10 & 16 & 10 \\
& & & 0 & & 0 \\
\hline
\end{tabular}

Bahasa anak dapat meningkat melalui model pembelajaran Student Teams Achievement Division (STAD), karena melalui model pembelajaran Student Teams Achievement Division (STAD) membuat suasana belajar lebih menyenangkan karena siswa dikelompokkan dalam kelompok yang heterogen, jadi anak tidak cepat bosan sebab mendapat kawan atau teman baru dalam pembelajaran.

\section{KESIMPULAN}

Berdasarkan hasil penelitian dan analisis data, dapat disimpulkan sebagai berikut :

a. Model pembelajaran Student Teams Achievement Division (STAD), pada pembelajaran dapat meningkatkan bahasa anak usia 5-6 tahun di TK ABA 30 Medan.

b. Peningkatan bahasa anak pada siklus I diperoleh bahasa anak masih rendah. Dari 16 anak 8 orang anak (50\%), pada kriteria cukup 6 orang anak (38\%) dan pada kriteria kurang 2 orang anak (12\%). Nilai rata-rata siklus I 
yaitu 61,11 (cukup). Pada siklus ini kemampuan klasikal belum tercapai karena kemampuan klasikal anak pada kriteria baik $(65-84)$ lebih rendah dari $75 \%$ yaitu $50 \%$.

c. Pada siklus II terjadi peningkatan yang signifikan, 7 orang anak (44\%) tergolong sangat baik, dan 9 orang anak $(56 \%)$ tergolong baik. Nilai ratarata bahasa anak yaitu 83,35 (baik). Dengan memberikan tindakan yang benar dan tepat seperti: menerapkan langkahlangkah pembelajaran dengan model pembelajaran Student Teams Achievement Division (STAD) serta memberikan motivasi dan pujian kepada anak, mampu meningkatkan bahasa anak. Pada siklus ini kemampuan klasikal anak sudah tercapai yaitu sebesar $100 \%$.

Dari simpulan diatas, maka saran-saran yang dapat diberikan yaitu:

a. Dalam kegiatan pembelajaran khususnya meningkatkan bahasa anak diharapkan guru dapat menggunakan model pembelajaran, salah satunya dengan menggunakan model pembelajaran Student Teams Achievement Division (STAD).

b. Stimulus diberikan agar anak semangat dalam melaksanakan tugas yang diberikan.

c. Untuk guru pendidikan anak usia dini diharapkan lebih kreatif dan inovatif dalam pembelajaran sehingga anak tidak merasakan kejenuhan saat pembelajaran.

d. Kepada peneliti yang akan melakukan penelitian sejenis diharapkan mampu mempersiapkan penelitian dengan matang sehingga hasil penelitian yang didapatkan lebih baik lagi.

\section{DAFTAR RUJUKAN}

Agustin, S. dkk. 2010. Buku Pintar Berbahasa dan Sastra Indonesia, Semarang: Aneka Ilmu.

Aqib, Zainal. 2011. Penelitian Tindakan Kelas. Bandung: Yrama Widya.

Dewi, Rosmala, 2010. Penelitian Tindakan Kelas. Medan: PPs Unimed.

Istarani. 2012. 58 Model Pembelajaran Inovatif. Medan : Iscom.

Kemendiknas. 2009. Permen Nomor 58 tahun 2009 Standar Perkembangan Anak. Jakarta.

Syarifah, Rismauli. 2015. Penerapan Model Pembelajaran STAD Dalam Meningkatkan Bahasa Anak Usia 5-6 Tahun Di Tk Aba 30 Tahun Ajaran 2014/2015. Medan. 